\title{
Zalecenia dotyczące uzupełniającego leczenia chorych na wczesnego raka piersi

\author{
Sprawozdanie z 13. Międzynarodowej Konferencji w St. Gallen
}

\author{
Marzena Wełnicka-Jaśkiewicz
}

\author{
Primary Therapy of Early Breast Cancer \\ XIII Breast Cancer Conference, St. Gallen 2013
}

XIII Konferencja, dotycząca leczenia wczesnego raka piersi, odbyła się w St. Gallen, w Szwajcarii, w marcu bieżącego roku. Jak zawsze cieszyła się ogromnym zainteresowaniem. Wzięło w niej udział około 3600 uczestników z blisko 90 krajów świata. Część edukacyjna Konferencji zogniskowała się przede wszystkim na zagadnieniach związanych z leczeniem zmiany pierwotnej i wielodyscyplinarnym podejściu do leczenia wczesnego raka piersi. Zgodnie z tradycją ostatniego dnia odbyła się debata uzgodnieniowa, w której wzięło udział 50 ekspertów z całego świata. Jedynym Polakiem uczestniczącym w debacie był prof. Jacek Jassem. Eksperci, odpowiadając na wcześniej przygotowane i jednoznacznie sformułowane pytania, starali się ustalić obowiązujące przez najbliższe dwa lata strategie postępowania odnoszące się do szeroko pojętego problemu leczenia wczesnego raka piersi.

\section{Molekularna klasyfikacja raków piersi}

Molekularna klasyfikacja raków piersi, zaadaptowana dla potrzeb klinicznych na poprzedniej Konferencji w St. Gallen, w zasadzie nie uległa większym zmianom, nieznacznie też zmieniły się wskazania do uzupełniającego leczenia w zależności od podtypu molekularnego raka piersi (tab. I i ll) [1].

Obecnie uznano, że podtyp luminalny A charakteryzuje się ekspresją zarówno receptorów ER jak i PgR [a nie jak poprzednio ER(+) i/lub PgR(+)] i niską wartością Ki67, przy czym większość ekspertów uznała wartość $20 \%$ za progową, różnicującą pomiędzy niską a wysoką wartością

\begin{tabular}{ll}
$\begin{array}{l}\text { Tabela I.Zmodyfikowana, w porównaniu z rokiem 2011, charakterystyka } \\
\text { uwarunkowanych genetycznie podtypów raka piersi }\end{array}$ \\
\hline $\begin{array}{ll}\text { Swoiste podtypy } \\
\text { raka piersi }\end{array}$ & Definicja kliniczno-patologiczna \\
\hline Luminalny A & ER i PgR (+) \\
& HER2 (-) \\
& Ki-67 niskie \\
Luminalny B & ER (+) \\
HER2 (-) & HER2 (-) \\
& i którakolwiek z cech: \\
& Ki-67 wysokie \\
& PgR (-)lub niskie \\
& ER (+) \\
Luminalny B & HER2 (+) \\
HER2 (+) & Ki-67 każda wartość \\
& PgR każda wartość \\
HER2 (+), nieluminalny & ER i PgR (-) \\
& HER2 (+) \\
Bazalny & Potrójnie ujemny \\
"basal-like" & ER (-) i PgR (-) \\
& HER2 (-) \\
\hline
\end{tabular}

ER - receptor estrogenowy, PgR - receptor progesteronowy, HER2 - receptor dla naskórkowego ludzkiego czynnika wzrostu typu 2

Ki67 (poprzednio wartość progową stanowiło 14\%). Biorąc jednak pod uwagę różnice pomiędzy laboratoriami i różną jakość wykonywanych badań, część ekspertów obawia się, że pewien odsetek chorych nie otrzyma właściwego leczenia (chemioterapii) w sytuacji niedoszacowania wartości Ki67. Dlatego też uznano, że jeśli to możliwe, powinno się 
Tabela II. Propozycje uzupełniającego leczenia w zależności od swoistego podtypu raka piersi

\begin{tabular}{|c|c|c|}
\hline Podtyp raka piersi & Rodzaj terapii & Uwagi \\
\hline Luminalny A & $\begin{array}{l}\text { HRTH dla wszystkich, najczęściej } \\
\text { samodzielna }\end{array}$ & $\begin{array}{l}\text { Tylko niewielka część chorych wymaga CHTH } \\
\text { (czynniki wymienione w tekście) }\end{array}$ \\
\hline Luminalny B, HER2 (-) & $\begin{array}{l}\text { HRTH dla wszystkich } \\
\text { CHTH dla większości } \\
\text { (antracykliny, taksoidy) }\end{array}$ & $\begin{array}{l}\text { Rodzaj CHTH zależy od stopnia ryzyka, } \\
\text { ekspresji ER i preferencji chorej }\end{array}$ \\
\hline Luminalny B, HER2 (+) & $\mathrm{CHTH}+$ anty-HER2 + HRTH & Brak dowodów pozwalających na odstąpienie od CHTH \\
\hline HER2 (+), nieluminalny & $\begin{array}{l}\text { CHTH + anty-HER2 } \\
\text { (antracykliny, taksoidy) }\end{array}$ & \\
\hline Bazalny (potrójnie ujemny) & $\begin{array}{l}\text { CHTH } \\
\text { (antracykliny, taksoidy, } \\
\text { leki alkilujące) }\end{array}$ & \\
\hline \multicolumn{3}{|l|}{ Specjalne typy histologiczne } \\
\hline $\mathrm{ER}(+)$ & HRTH & Typ gruczołowo-torbielowaty z reguły nie wymaga \\
\hline $\mathrm{ER}(-)$ & $\mathrm{CHTH}$ & uzupełniającego leczenia [jeśli N(-)] \\
\hline
\end{tabular}

ER - receptor estrogenowy, PgR - receptor progesteronowy, HER2 - receptor dla naskórkowego ludzkiego czynnika wzrostu typu 2, CHTH — chemioterapia, $\mathrm{HRTH}$ - hormonoterapia

w takich wątpliwych przypadkach wykonywać badania genetyczne. Powinny one obejmować również niektóre chore ER(+) HER2(-), np. z przerzutami do mniej lub czterech węzłów chłonnych czy poniżej 35 r.ż. W takich sytuacjach rekomendowanym badaniem jest Oncotype Dx. Doprecyzowano również charakterystykę podtypu luminalnego $B$ HER2(-), którego poza ekspresją receptora ER cechuje także wysoka wartość Ki67 i/lub brak lub niska ekspresja PgR $(<20 \%)$. Cechami niezbędnymi dla podtypu luminalnego $B$ HER2(+) jest oczywiście ekspresja receptorów HER2 i ER, niezależnie od ekspresji PgR i Ki67.

Eksperci wycofali się z poprzednio sformułowanego stwierdzenia, że niski stopień zróżnicowania raka G3 może stanowić równoważnik dla wysokiej wartości K67.

\section{Leczenie miejscowe Chirurgia}

Za bezwzględne przeciwwskazanie do leczenia oszczędzającego pierś (BCT) uznano jedynie brak możliwości przeprowadzenia uzupełniającej radioterapii oraz obecność raka inwazyjnego lub DCIS w marginesie wycięcia guza po kilkukrotnych zabiegach poszerzających [4]. Zaakceptowano określenie minimalnego marginesu jako brak inwazyjnego raka w obrębie wytuszowanych marginesów wokół guza; część ekspertów za bezpieczny uznała margines $1 \mathrm{~mm}$. Przeciwwskazaniami względnymi, które należy mieć na uwadze i które powinny być przedyskutowane z chorą, są: młody wiek chorej (poniżej 35 lat), rozległe i rozproszone mikrozwapnienia, wieloośrodkowość zmian, lokalizacja guza w pobliżu brodawki oraz mutacja w genach BRCA1 lub BRCA2.

W odniesieniu do limfadenektomii pachowej eksperci podtrzymali swoje stanowisko z poprzedniej Konferencji, podkreślając, że nie ma konieczności usuwania pachowych węzłów chłonnych u chorych, u których stwierdzono przerzuty do jednego lub dwóch wartowniczych węzłów chłonnych, pod warunkiem planowanej radioterapii na całą pierś lub w przypadku mastektomii na ścianę klatki piersiowej [5]. Zasady te nie odnoszą się do chorych z klinicznie przerzutowymi węzłami chłonnymi.

\section{Radioterapia}

Znakomita większość ekspertów była zgodna, że skrócone schematy uzupełniającej radioterapii (40 Gy/15 fr lub 42,5/16 fr) powinny stanowić standard postępowania u większości chorych, niezależnie od planowanego boostu na lożę po usuniętym guzie [6]. Uznano również, że u określonej grupy chorych, np. w starszym wieku i obciążonych istotnymi współistniejącymi chorobami, można w miarę bezpiecznie uniknąć radioterapii po zabiegach typu BCT. Natomiast opcja różnych technik częściowego napromieniania piersi nie spotkała się z akceptacją ekspertów.

Większość wskazań do radioterapii po mastektomii nie uległa zmianie w porównaniu z zaleceniami z roku 2011; potwierdzono zasadność uzupełniającej radioterapii, jeśli przerzuty były w więcej niż trzech usuniętych węzłach chłonnych lub jeśli przerzuty stwierdzono w węźle wartowniczym, a następnie nie podjęto limfadenektomii pachowej. Radioterapia powinna być przeprowadzona również w sytuacjach dodatnich „głębokich" marginesów i w przypadkach guzów o średnicy większej od $5 \mathrm{~cm}$. Ponadto uznano, że sam fakt usunięcia mniej niż 8 węzłów chłonnych (bez obecności przerzutów) nie stanowi wskazania do uzupełniającego napromieniania.

Większość ekspertów była zdania, że u chorych po limfadenektomii pachowej nie ma wskazań do uzupełniającej radioterapii na tę okolicę. 


\section{Uzupełniające leczenie systemowe Hormonoterapia przed menopauzq}

Tamoksyfen nadal pozostaje leczeniem z wyboru w uzupełniającej hormonoterapii chorych przed menopauzą. W świetle najnowszych wyników badań wydaje się, że co najmniej część chorych odniesie korzyść z wydłużenia czasu leczenia do 10 lat [7]. Większość ekspertów uważa, że nie ma potrzeby kojarzenia tamoksyfenu z farmakologiczną supresją jajników, ale mniej niż połowa sądzi, że chore poniżej 40 r.ż. mogą z takiej terapii odnieść korzyść. Podtrzymano pozytywną opinię na temat możliwości kojarzenia inhibitorów aromatazy (IA) z supresją jajników, jednak wyłącznie u chorych z jednoznacznymi przeciwwskazaniami do tamoksyfenu.

\section{Hormonoterapia po menopauzie}

Jeszcze raz podkreślono, że hormonoterapia wyłącznie tamoksyfenem stanowi dobrą opcję leczenia dla części chorych po menopauzie. Blisko 90\% ekspertów uważa, że jeżeli strategia terapii zakłada stosowanie zarówno tamoksyfenu, jak i IA, to u chorych o wysokim ryzyku IA powinny być zastosowane jako pierwsze. Natomiast wydłużenie hormonoterapii powyżej pięciu lat jest rekomendowane szczególnie u chorych, u których stwierdzono przerzuty do węzłów chłonnych i u których leczenie zaczęto od tamoksyfenu, a IA były stosowane krócej niż pięć lat. Ostatnio opublikowane wyniki badania MA.17 wskazują, że największą korzyść z zastosowania letrozolu po pięciu latach przyjmowania tamoksyfenu mogą odnieść chore, które rozpoczynały terapię, będąc przed menopauzą, i weszły w okres przekwitania w trakcie leczenia tamoksyfenem [8, 9].

\section{Chemioterapia}

Czynnikami przemawiającymi za włączeniem chemioterapii do leczenia uzupełniającego uznano stopień złośliwości G3, wysoką wartość Ki67, niską ekspresję receptorów hormonalnych, nadmierną ekspresję HER2, raka piersi „potrójnie ujemnego", obecność przerzutów w co najmniej trzech węzłach chłonnych, wysoki indeks nawrotu oszacowany w testach molekularnych Oncotype DX lub 70-genowym. Eksperci byli zgodni, że obecność przerzutów w pojedynczych węzłach chłonnych sama w sobie nie jest wskazaniem do włączenia chemioterapii, ale większość zastosowałoby to leczenie w przypadku przerzutów do więcej niż trzech węzłów. Połowa ekspertów uważa, że chore młode, poniżej 35 r.ż. powinny otrzymać z założenia uzupełniającą chemioterapię.

Chore o cechach raka luminalnego A są uznawane za mniej wrażliwe na chemioterapię, ale jej dołączenie do hormonoterapii można brać pod uwagę w sytuacji guzów o dużej objętości - wówczas sugerowane są schematy mniej intensywne, np. AC, CMF czy TC. Z kolei większość ekspertów uznała, że u chorych na raka o podtypie luminalnym $B$ (HER2-) należy zawsze rozważyć udział chemioterapii opartej na antracyklinach [10]. Udział taksanów w tej grupie chorych nie został jednoznacznie zdefiniowany, ale był preferowany w przypadku chorych z nadekspresją receptorów HER2.

W odniesieniu do raków „potrójnie ujemnych" eksperci podtrzymali swoje stanowisko na temat stosowania antracyklin i taksanów, jednocześnie nie rekomendując związków platyny ani schematów typu dose-dense.

\section{Leczenie anty-HER2}

Nie zmieniły się zalecenia dotyczące uzupełniającego leczenia chorych z nadekspresją/amplifiakacją HER2. Wszyscy eksperci uznali jeden rok terapii za optymalny czas leczenia. Większość ekspertów była zdania, że do leczenia powinni być kwalifikowani wszyscy chorzy z guzem powyżej $5 \mathrm{~mm}$ i że leczenie trastuzumabem może być kojarzone $z$ taksanami. Uznano również, że w przypadku przeciwwskazań do chemioterapii możliwe jest skojarzenie trastuzumabu z hormonoterapią lub, w przypadku braku ekspresji receptorów steroidowych, monoterapia trastuzumabem powinna być leczeniem z wyboru.

\section{Leczenie neoadiuwantowe}

Ponad 90\% ekspertów głosowało za stosowaniem trastuzumabu również u chorych zakwalifikowanych do neoadiuwantowej chemioterapii. Podobnie eksperci byli zdania, że w przypadku silnej ekspresji receptorów steroidowych, szczególnie przy niskim indeksie proliferacji, opcja hormonoterapii powinna być preferowana. Leczenie należy prowadzić do uzyskania maksymalnej odpowiedzi.

Ponadto eksperci uznali, że regularna obserwacja po zakończeniu aktywnego leczenia (z wyłączeniem długotrwałej hormonoterapii) jest uzasadniona, ale powinna być nadzorowana przez wykwalifikowaną pielęgniarkę, a nie przez specjalistę onkologa [11]. Blisko 80\% ekspertów uważa, że poza mammografią nie ma wskazań do innych, rutynowych badań diagnostycznych.

\section{Podsumowanie}

Tegoroczna Konferencja w St. Gallen nie stanowiła zasadniczego przełomu w podejściu do leczenia wczesnego raka piersi. Uporządkowała i zweryfikowała jednak poprzednie ustalenia, a jej myślą przewodnią było potwierdzenie, że rak piersi stanowi szerokie spektrum różnych chorób, z których każda wymaga specyficznego leczenia.

Nostalgicznym aspektem dla wielu uczestników byłfakt, że była to ostatnia Konferencja organizowana w St. Gallen, następna odbędzie się w Wiedniu w dniach 18-21 marca 2015 r. Mamy nadzieję, że jeszcze wrócimy do St. Gallen.

\section{Prof. dr hab. n. med. Marzena Wełnicka-Jaśkiewicz}

Klinika Onkologii i Radioterapii

Uniwersytet Medyczny

ul. Dębinki 7, 80-211 Gdańsk

e-mail:mwelj@gumed.edu.pl 


\section{Piśmiennictwo}

1. Goldhirsch A, Wood WC, Coates AS i wsp. Strategies for subtypes dealing with the diversity of breast cancer: highlights of the St Gallen International Expert Consensus on the Primary Therapy of Early Breast Cancer 2011. Ann Oncol 2011; 22: 1736-1747.

2. Nielsen TO, Polley M-YC, Leung SCY i wsp. An international Ki-67 reproducibility study. Prezentowane na 35 . Konferencji Raka Piersi w San Antonio, 2012 (Abstr. S4-6).

3. Prat A, Cheang MC, Martin M i wsp. Prognostic significance of progesterone receptor-positive tumor cells within immunohistochemically defined luminal a breast cancer. J Clin Oncol 2013; 31: 203-209.

4. Rutgers E. Who should NOT have breast conservation? The Breast 2013; 22 (Supp 1); S13 (Abstr. SP7.04) (manuskrypt w przygotowaniu).

5. Giuliano AE, Hunt KK, Ballman KV i wsp. Axillary dissection vs no axillary dissection in women with invasive breast cancer and sentinel node metastasis. JAMA: The Journal of the American Medical Association 2011; 305: 569-575.

6. Yarnold JR. The UKSTART (standardisation of breast radiotherapy) Trials: 10-year follow-up results. Prezentowane na 35. Konferencji Raka Piersi w San Antonio, 2012 (Abstr. S4-1).
7. Davies C, Pan H, Godwin J i wsp. Long-term effects of continuing adjuvant tamoxifen to 10 years versus stopping at 5 years after diagnosis of oestrogen receptor-positive breast cancer: ATLAS, a randomised trial. The Lancet 2013; 381: 805-816.

8. Goss $\mathrm{PE}$, Ingle $\mathrm{JN}$, Martino $\mathrm{S}$ i wsp. A randomized trial of letrozole in postmenopausal women after five years of tamoxifen therapy for early-stage breast cancer. N Engl J Med 2003; 349: 1793-1802.

9. Goss PE, Ingle JN, Martino S i wsp. Impact of premenopausal status at breast cancer diagnosis in women entered on the placebo-controlled NCIC CTG MA17 trial of extended adjuvant letrozole. Ann Oncol 2013; 24: 355-361.

10. Cheang MC, Voduc KD, Tu D i wsp. Responsiveness of intrinsic subtypes to adjuvant anthracycline substitution in the NCIC.CTG MA.5 randomized trial. Clin Cancer Res 2012; 18: 2402-2412.

11. Smith I. Follow up tests to detect recurrent disease: patient reassurance or medical need? The Breast 2013; 22 (Supp 1); S17 (Abstr. SP9.05) (manuskrypt w przygotowaniu). 